DOI: 10.1515/LPTS-2015-0008

\title{
RES-E SUPPORT POLICIES IN THE BALTIC STATES: ELECTRICITY PRICE ASPECT (PART II)
}

\author{
V. Bobinaite, I. Priedite \\ Institute of Physical Energetics, \\ 21 Aizkraukles Str., Riga, LV-1006, LATVIA
}

Increasing volumes of electricity derived from renewable energy sources (RES-E) affect the electricity market prices and the prices for final electricity consumers in the Baltic States. The results of a multivariate regression analysis show that in 2013 the RES-E contributed to decreasing the electricity market prices in the Baltic States. However, the final electricity consumers pay for the promotion of RES-E through the approved RES-E component which has a tendency to increase. It is estimated that in 2013 the net benefits from the wind electricity promotion were achieved in Lithuania and Latvia while the net cost - in Estonia. This suggests that the economic efficiency of the wind electricity support scheme based on the application of feed-in tariffs was higher than that based on the feed-in premium.

Keywords: renewable energy sources, electricity, promotional scheme, feed-in tariff, feed-in premium, subsidies, effectiveness.

\section{INTRODUCTION}

The electricity produced from renewable energy sources (RES-E) and the economy nexus are under consideration worldwide. So far, many open questions remain, as to, for example, the necessity of support for RES-E, the cost and benefits of RES-E technology implementation at the macroeconomic scale, etc. Solution of these problems would help to make decisions on the future development of the renewable energy sector and on the actions to be taken.

Thus far, the primary attention is directed towards discovering and assessing the link between the increased RES-E production volume and the wholesale and retail electricity prices [1-4], since this allow the expedience of RES-E use to be substantiated economically.

Lately, this issue was discussed in detail in the countries which historically had stable RES-E support policies and achieved good results [3,4], while little analysed in the countries with frequently alternating and sometimes insufficiently developed RES-E support policies. Such is the case of the Baltic States, with specific domestic power sector and electricity markets depending on different local resources or relying on the electricity import from neighbouring countries [5, 6], achieving different levels of national electricity markets' liberalisation and undergoing integration of electricity networks into the EU ones. 
Thus, this paper aims at filling the gap in the structured knowledge about the impact of different RES-E support schemes on electricity prices in the Baltic States. To the authors' knowledge, this is one of the first attempts to assess the relationships between the determinants in the Baltic States, provide comparison of computations and give suggestions as to the energy policy development. The impact of support schemes on the electricity prices is assessed by taking into account the dependence of electricity prices on different factors, with the support for RES-E being one of them.

\section{DATA AND METHOD}

\subsection{Data}

The analysis presented in the work is based on the statistical data provided by the transmission system operators of the Baltic States: LITGRID [7], ELERING [8] and "Augstsprieguma tikls" [9]. These data are used as independent variables in multivariate regression models. Another type statistical data, e.g. the day-ahead electricity prices in the Baltic States, are taken from Nord Pool Spot AS database [10]. These data are used as dependent variables in the multivariate regression models. The time span under consideration 2013 (January) - 2014 (March). This span coincides with the time during which a day-ahead market was finally launched in Latvia (thus, all the Baltic States were trading in this market). For analysis the average hourly statistical data are used. They have been processed, and for further analysis natural logarithms of statistical data are taken. Logarithmical transforming of the variables in a multivariate regression model is a common way to handle the situations where a non-linear relationship exists between the independent and the dependent variables. Using the logarithm of variables instead of the un-logged form makes the relationship non-linear, while still preserving the linear model [11]. Logarithmic transformations are also a convenient means of transforming a highly skewed variable into a normal one [11].

\subsection{Method}

It is assumed that an efficient RES-E support scheme is effective, i.e. it helps to raise the RES-E production volume. It is expected (see, e.g. [1,2,4] and [12]) that the increased production volume of RES-E and its trade via the market will reduce the electricity market price. Even in the cases when the excessive RES-E volume is not sold in the market, this amount can affect the electricity market price through the impact on the residual electricity demand, which will decrease and reduce this price. To assess the impact of RES-E support scheme on the electricity market prices, a multivariate regression method is used.

The advantage of the multivariate regression method is that it allows explaining the impact of RES-E production volume on the electricity market prices in the context of various economic, environmental, technological, social, seasonal, and other factors. Thus, the method could also be used to explain the process of electricity price formation in the Baltic States by emphasising the impact of RES-E support schemes. 
Since the electricity market price is influenced by general and country-specific factors, three expressions of multivariate regression models have been prepared, one for each country.

The multivariate regression model for formation of the electricity market price in Lithuania acquires the form:

$$
\begin{aligned}
& \ln \mathrm{PRICE}_{t}=\beta_{0}+\beta_{1} \cdot \ln W I N D_{t}+\beta_{2} \cdot \ln \mathrm{IMPORT}_{L V t}+\beta_{3} \cdot \ln I M P O R T_{R U t}+ \\
& +\beta_{4} \cdot \ln \mathrm{IMPORT}_{B Y t}+\beta_{5} \cdot \ln \mathrm{IEMAND}_{t}+\beta_{7} \cdot D D_{t k}+\beta_{8} \cdot M D_{t l}+\varepsilon
\end{aligned} .
$$

Formation of the electricity market price in Latvia is described by the following equation:

$$
\begin{aligned}
& \ln \text { PRICE }_{t}=\beta_{0}+\beta_{1} \cdot \ln W_{I N D_{t}}+\beta_{2} \cdot \ln \mathrm{HYDRO}_{t}+\beta_{3} \cdot \ln R E S_{\text {small }}+ \\
& +\beta_{4} \cdot \ln \text { THERMAL }_{t}+\beta_{5} \cdot \ln \left(E_{\text {EXORT }}-\mathrm{IMPORT}_{t}\right)+, \\
& +\beta_{6} \cdot \ln D E M A N D+\beta_{7} \cdot D D_{t k}+\beta_{8} \cdot M D_{t l}+\varepsilon
\end{aligned}
$$

and in Estonia - by the equation:

$$
\begin{aligned}
& \ln P_{R I C E}=\beta_{0}+\beta_{1} \cdot \ln W I N D_{t}+\beta_{2} \cdot \ln \operatorname{IMPORT}_{F I t}+\beta_{3} \cdot \ln \mathrm{EXPORT}_{R U t}+ \\
& +\beta_{4} \cdot \ln \mathrm{EXPORT}_{L V t}+\beta_{5} \cdot \ln D E M A N D_{t}+\beta_{7} \cdot D D_{t k}+\beta_{8} \cdot M D_{t l}+\varepsilon
\end{aligned},
$$

where $\ln \quad$ is the natural logarithm;

PRICE $_{t}$ is the average day-ahead electricity price;

$t \quad$ is the time;

$R E S_{\text {smallt }} \quad$ is the average hourly production volume of $R E S-E$ in small PPS;

$W I N D_{t} \quad$ is the average hourly production volume of wind electricity;

$H Y D R O_{t} \quad$ is the average hourly production volume of hydro electricity;

THERMAL ${ }_{t}$ is the average hourly production volume of thermal electricity;

$E X P O R T_{R U t}$ is the average hourly electricity export volume to Russia;

$E X P O R T_{L V t}$ is the average hourly electricity export volume to Latvia;

$I M P O R T_{L V t}$ is the average hourly electricity import volume from Latvia;

$I M P O R T_{R U t}$ is the average hourly electricity import volume from Russia;

$I M P O R T_{F I t}$ is the average hourly electricity import volume from Finland;

$I M P O R T_{B Y t}$ is the average hourly electricity import volume from Belarus;

$D E M A N D_{t}$ is the electricity consumption volume at a certain price;

$D D_{t k} \quad$ is the daily dummies $(k=1,2, \ldots 6)$;

$M D_{t l} \quad$ is the monthly dummies $(l=1,2, \ldots 11)$.

The impact of volumes of wind electricity on the electricity market price is computed as

$$
\Delta P=P_{t} \cdot\left(\frac{Q_{\text {wind } ; t}-Q_{\text {wind } ; t-1}}{Q_{\text {wind } ; t-1}}\right) \cdot \beta_{1},
$$


where $\Delta P \quad$ is the change in electricity market price due to the changes in production volumes of wind electricity;

$P_{t} \quad$ is the electricity market price at time $t$;

$Q_{\text {wind: } t}$ is the wind electricity production volume at time $t$;

$Q_{\text {wind; } t-1}$ is the wind electricity production volume at time $t-1$;

$\beta_{1} \quad$ is the wind electricity elasticity of the electricity market price.

The subsidy for wind electricity generators included in the final price for electricity is calculated as

$$
S_{t}=\frac{\sum_{i=1}^{n}\left(R_{i, t}-P_{t}\right) \cdot Q_{i ; t}}{Q_{F E C V}},
$$

where $S_{t} \quad$ is the subsidy for wind electricity generators included in the final price for electricity at time $t$;

$i \quad$ is the wind electricity generator (number of generators varies in a range of $1-n$ );

$R_{i, t} \quad$ is the revenue of the $i$-th generator at time $t$;

$Q_{i, t} \quad$ is the electricity production volume by the $i$-th generator at time $t$;

$Q_{F E C V}$ is the final electricity consumption volume during a year.

The net benefit / cost of support scheme for wind electricity production is computed from the following equation:

$$
B C=|\Delta P|-\Delta S,
$$

where $\Delta S \quad$ is the change in subsidy for wind electricity generators included in the final price for electricity. It is computed as a difference between $S_{t}$ and $S_{t-1}$;

$\Delta P \quad$ is the change in the electricity market price due to changes in the production volume of wind electricity.

The net benefit of increased volume of wind electricity is achieved at $B C>0$. This means that due to support to the wind electricity production and increased wind electricity production volumes, the decrease in the electricity market price was greater than the increase in subsidies for wind electricity generators. However, at $\mathrm{BC}<0$ the net cost is suffered. This means that, despite the support provided to wind electricity generators and the increase in wind electricity production volumes, the decrease in the electricity market price was smaller than the increase in subsidies for wind electricity generators. 


\section{RESULTS}

\subsection{Results of a multivariate regression analysis}

Table 1 shows the results of multivariate regression analysis. The peculiarity of regression models consists in the following: all coefficients of independent variables of regression models are statistically significant at $10 \%$ and $5 \%$ levels. The results show that such fundamental factors as volumes of $R E S-E$, demand for electricity, electricity production structure and international trade volumes as well as seasonal factors influenced the electricity market prices in the Baltic States.

It was revealed that the electricity market prices were increasing with the electricity consumption volumes. Also, it was found that increase in the production volume of wind electricity reduced these prices. The wind electricity production volume elasticity of electricity market price was [-0.0283;-0.0398] in Estonia, $[-0.0370 ;-0.0418]$ in Latvia, and $[-0.0365 ;-0.0830]$ in Lithuania during the analysed time. This implies that a $1 \%$ increase in the production volume of wind electricity in Estonia, Latvia and Lithuania resulted in the $0.03-0.04 \%, 0.04 \%$ and $0.04-0.08 \%$ decrease, respectively, in the electricity market prices in the Baltic States.

The case of Latvia revealed that increased RES-E production by small-scale power plants had even a greater reducing effect than that of wind electricity. The elasticity of the electricity market price for RES-E production volume by small-scale PPs was $[-0.9014 ;-1.8943]$. The volume of electricity production by large-scale hydro PPs was expected to be sufficient for increasing the electricity market price by $0.02 \%$, whereas the electricity production volume by thermal PPs was statistically insignificant in Latvia within the time under analysis. Considering the value of $\mathrm{R}^{2}$ adjusted (i.e. an adjusted determination coefficient), it could be stated that regression model (3) described best the changes in electricity market price in Latvia. This model assumed that this price in Latvia changed because of wind electricity production volume, smal-scale RES-E, hydro power, electricity consumption volume, as well as depending on the season. These factors could explain $69.4 \%$ of changes in the electricity market price.

Considering the value of $\mathrm{R}^{2}$-adjusted, it could be argued that multivariate regression model (3) was the best for explaining the electricity market price formation in Estonia. This model assumed that the electricity market price is a function of wind electricity production volume, volume of electricity exported to Russia, electricity consumption volume, and seasonality. These price formation factors could explain $55.61 \%$ of changes in the electricity market price in Estonia.

In Lithuania, the electricity market price formation could be best desribed by the development of three factors: the wind electricity production volume, the electricity consumption volume, and the seasonality, which were responsible for $58.81 \%$ of the electricity market price development in Lithuania (see model (2)). The electricity market price had a tendency to increase in summer and autumn. Calculations show that the seasonal variables' elasticity of electricity market price was 0.4420 (June), 0.3331 (July), 0.3653 (August) and 0.5583 (September). The difference is explained by congestion in Latvia-Estonia interconnections in summer [6]. There 
है

\begin{tabular}{|c|c|c|c|c|c|c|c|c|c|c|c|c|c|c|c|c|}
\hline \multirow{4}{*}{ 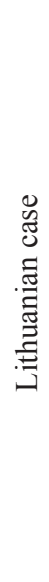 } & $\mathcal{I}$ & 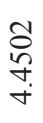 & $\begin{array}{l}0 \\
\infty \\
0 \\
0 \\
0 \\
\end{array}$ & & & & 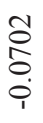 & & & & & $i_{\nu}^{\infty}$ & $\stackrel{\circ}{z}$ & $\begin{array}{l}\stackrel{0}{\pi} \\
\stackrel{n}{0}\end{array}$ & $\frac{\hat{0}}{\frac{1}{0}}$ & 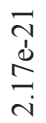 \\
\hline & $\approx$ & 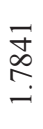 & $\begin{array}{l}0 \\
\infty \\
0 \\
0 \\
0 \\
1\end{array}$ & & & & $\begin{array}{l}\hat{8} \\
\dot{8} \\
\dot{\varphi} \\
\dot{1}\end{array}$ & & & & & z & z & $\frac{d}{\frac{d}{0}}$ & $\begin{array}{l}\text { ते } \\
\underset{0}{0}\end{array}$ & 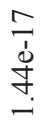 \\
\hline & $\overparen{d}$ & 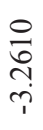 & $\begin{array}{l}n \\
0 \\
0 \\
0 \\
0 \\
i\end{array}$ & & & & & & & & $\frac{n}{\hat{\alpha}}$ & $\stackrel{\circ}{z}$ & $\stackrel{\infty}{\nu}$ & $\begin{array}{l}\bar{\infty} \\
\infty \\
n \\
0\end{array}$ & $\begin{array}{l}\text { Oे } \\
\stackrel{0}{0}\end{array}$ & 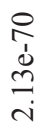 \\
\hline & 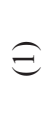 & 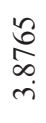 & $\begin{array}{l}0 \\
\tilde{n} \\
0 \\
0 \\
i\end{array}$ & & & & & & & & & z & $\stackrel{0}{\nu}$ & $\begin{array}{l}\sqrt[n]{2} \\
\stackrel{y}{0} \\
0\end{array}$ & $\begin{array}{l}\hat{\tilde{N}} \\
\overrightarrow{0}\end{array}$ & 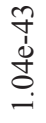 \\
\hline \multirow{4}{*}{ 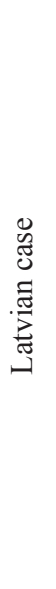 } & $\overparen{\mathcal{I}}$ & 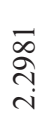 & $\begin{array}{l}\infty \\
\underset{+}{+} \\
\stackrel{0}{0}\end{array}$ & $\begin{array}{l}\frac{1}{8} \\
\stackrel{2}{\circ} \\
\text { i. }\end{array}$ & $\begin{array}{l}0 \\
0 \\
0 \\
0 \\
1\end{array}$ & $\begin{array}{l}\infty \\
0 \\
0 \\
0 \\
0\end{array}$ & & & & & $\begin{array}{l}n \\
0 \\
0 \\
o \\
0\end{array}$ & $\stackrel{\circ}{z}$ & $\stackrel{\circ}{z}$ & $\begin{array}{l}\stackrel{2}{y} \\
\stackrel{f}{0}\end{array}$ & $\frac{\stackrel{n}{n}}{\stackrel{0}{0}}$ & $\begin{array}{l}\tilde{n} \\
\dot{d} \\
\stackrel{\Delta}{\hat{N}}\end{array}$ \\
\hline & $\approx$ & $\begin{array}{l}\hat{\tilde{\sigma}} \\
\frac{1}{\pi}\end{array}$ & $\begin{array}{l}\hat{N} \\
\hat{\delta} \\
\dot{1}\end{array}$ & $\begin{array}{l}\stackrel{f}{+} \\
\stackrel{\infty}{\rightarrow} \\
\rightarrow-1\end{array}$ & $\begin{array}{l}\stackrel{0}{2} \\
0 \\
0\end{array}$ & & & & & & $\begin{array}{l}0 \\
\stackrel{0}{\sigma} \\
\dot{\sigma}\end{array}$ & $\sum_{\lambda}^{\infty}$ & $\sum_{\lambda}^{\infty}$ & $\begin{array}{l}\text { ㅁ } \\
\text { ல! } \\
\dot{0}\end{array}$ & $\begin{array}{l}\stackrel{1}{\infty} \\
\stackrel{\sim}{\Im} \\
\stackrel{0}{0}\end{array}$ & $\begin{array}{l}0 \\
\stackrel{0}{0} \\
\dot{0} \\
\stackrel{0}{0}\end{array}$ \\
\hline & $\overparen{d}$ & 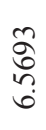 & $\begin{array}{l}\stackrel{P}{0} \\
\text { ô. } \\
\stackrel{0}{1}\end{array}$ & 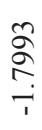 & & & & & & & $\begin{array}{l}\infty \\
\stackrel{\infty}{n} \\
\vdots \\
0\end{array}$ & $\sum_{\lambda}^{\infty}$ & $\sum_{\lambda}^{\infty}$ & $\begin{array}{l}\overline{8} \\
\text { bे } \\
0\end{array}$ & $\frac{\text { సे }}{\stackrel{0}{0}}$ & $\begin{array}{l}\hat{0} \\
\dot{0} \\
m \\
a \\
a\end{array}$ \\
\hline & 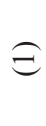 & 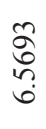 & $\begin{array}{l}\stackrel{P}{0} \\
\hat{0} \\
0 \\
1\end{array}$ & 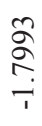 & & & & & & & \begin{tabular}{l}
$\stackrel{\infty}{n}$ \\
\multirow{2}{0}{} \\
0
\end{tabular} & $\stackrel{\infty}{\infty}$ & $\stackrel{\infty}{\infty}$ & $\begin{array}{l}\overline{8} \\
\text { ర్ } \\
0\end{array}$ & 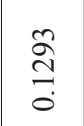 & $\begin{array}{l}\hat{b} \\
\dot{j} \\
m \\
\cdots \\
a\end{array}$ \\
\hline \multirow{4}{*}{ 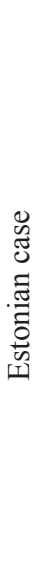 } & $\stackrel{f}{(t}$ & $\begin{array}{l}\hat{n} \\
\hat{\alpha} \\
\dot{m}\end{array}$ & $\begin{array}{l}\bar{n} \\
\hat{\sigma} \\
\dot{0}\end{array}$ & & & & & $\begin{array}{l}\infty \\
0 \\
0 \\
0 \\
0 \\
1\end{array}$ & $\begin{array}{l}0 \\
+ \\
0 \\
0 \\
0\end{array}$ & $\begin{array}{l}\infty \\
\hat{\infty} \\
0 \\
0 \\
0\end{array}$ & & $\stackrel{0}{z}$ & $\stackrel{0}{z}$ & $\begin{array}{l}\stackrel{+}{\vec{~}} \\
\stackrel{\sim}{0}\end{array}$ & $\begin{array}{l}\bar{\sigma} \\
\frac{1}{0}\end{array}$ & 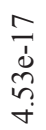 \\
\hline & (2) & $\begin{array}{l}+ \\
\stackrel{\infty}{0} \\
\stackrel{5}{+} \\
\\
\end{array}$ & $\begin{array}{l}0 \\
0 \\
0 \\
0 \\
0 \\
1\end{array}$ & & & & & 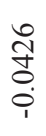 & & & 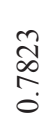 & z & $i_{\nu}^{\infty}$ & $\begin{array}{l}\overline{0} \\
n \\
n \\
0\end{array}$ & $\frac{\stackrel{n}{\simeq}}{\frac{1}{0}}$ & 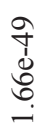 \\
\hline & (d) & $\begin{array}{l}\stackrel{\circ}{\circ} \\
\text { } \\
\dot{r}\end{array}$ & $\begin{array}{l}\infty \\
\text { ô } \\
\text { ஸे }\end{array}$ & & & & & & & & & $\stackrel{\infty}{\infty}$ & $\stackrel{\infty}{\nu}$ & $\begin{array}{l}\stackrel{+}{\sigma} \\
\stackrel{+}{0}\end{array}$ & $\frac{\vec{\sim}}{\stackrel{0}{0}}$ & $\begin{array}{l}\tilde{n} \\
\dot{j} \\
\tilde{n} \\
0\end{array}$ \\
\hline & 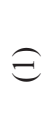 & 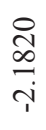 & & & & & & & & & $\begin{array}{l}\stackrel{N}{\hat{N}} \\
\infty \\
0 \\
0\end{array}$ & $\ddot{z}$ & $\sum_{\lambda}^{\infty}$ & $\begin{array}{l}\infty \\
\stackrel{\infty}{a} \\
\stackrel{+}{0} \\
\stackrel{0}{0}\end{array}$ & 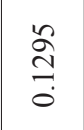 & 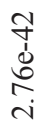 \\
\hline \multicolumn{2}{|c|}{ 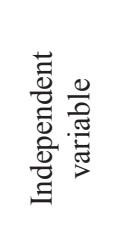 } & 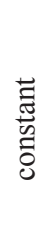 & $\sum_{\exists}^{\text {云 }}$ & 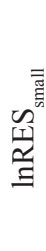 & 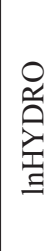 & 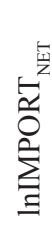 & 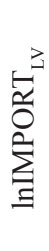 & 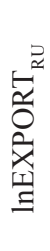 & 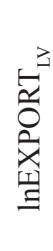 & 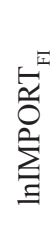 & 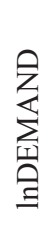 & 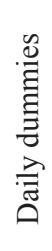 & 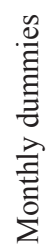 & 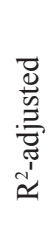 & 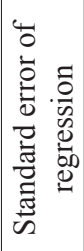 & 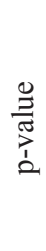 \\
\hline
\end{tabular}


were also prepared two regression models which took into account the effect of international trade. It was established that a $1 \%$ increase in the electricity import from Latvia allowed the electricity market price to be reduced by $0.06 \%$ (model (3)) and 0.07\% (model (4)) in Lithuania.

Thus, the results of analysis reveal that among various fundamental factors the production volume of wind electricity was a relevant factor of the electricity market price. This factor was found to be negatively related to the electricity market prices in the Baltic States, which suggests that increasing volumes of wind electricity were beneficial for the countries since this contributed to the decrease in the electricity market prices in 2013 .

\subsection{Impact of the wind electricity production volume on the market prices}

In 2013, a rise in the wind electricity production volumes in the Baltic States was observed. The greatest rate of such a rise was in Estonia $-21.9 \%$, folowed by $11.6 \%$ rise in Lithuania, and 5.28\% rise in Latvia. Considering multivariate regression model (3) for Estonia, model (3) for Latvia and model (2) for Lithuania, it was estimated that due to the increased production of wind electricity, the market price could decrease in the monetary terms (Fig. 1).

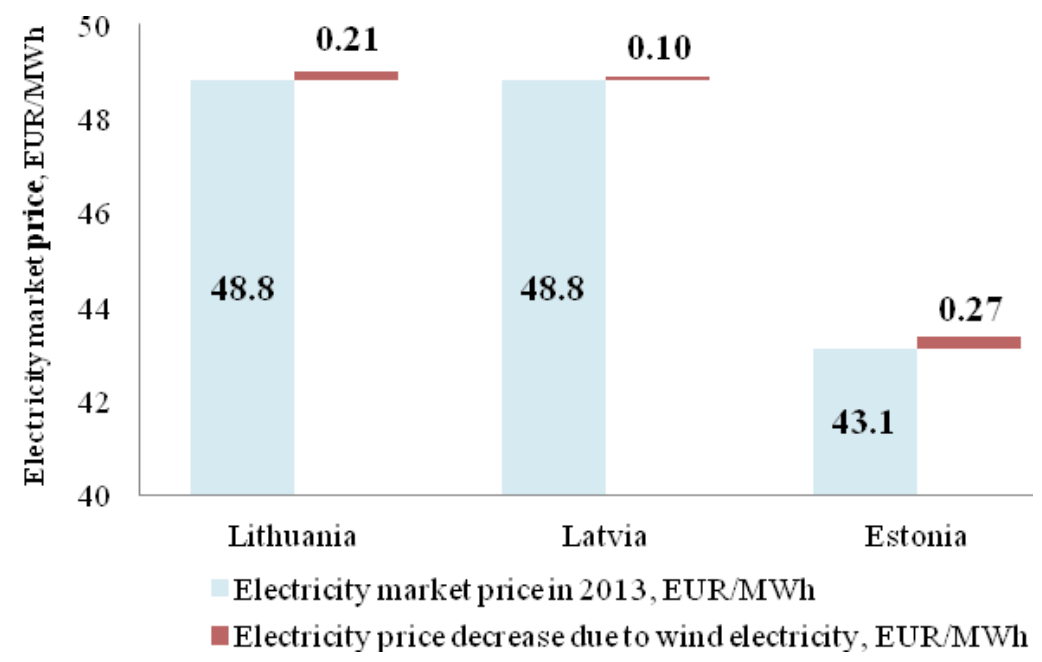

Fig. 1. The impact of wind electricity production volume on the market price (own computations).

Figure 1 shows the actual electricity market prices in 2013. In Lithuania and Latvia, these prices were equal, i.e. 48.8 EUR/MWh. In Estonia, the annual average electricity market price was $12 \%$ lower. Calculations show that at the volume of wind electricity produced in the Baltic States equal to that in 2012, the electricity market price could have been higher by $0.27 \mathrm{EUR} / \mathrm{MWh}$ in Estonia, by $0.21 \mathrm{EUR} /$ $\mathrm{MWh}$ - in Lithuania, and by $0.10 \mathrm{EUR} / \mathrm{MWh}$ - in Latvia. Thus, it was demonstrated that the increased wind electricity production volume reduced the electricity market prices in the Baltic States. As a result, benefits from the wind electricity support schemes were achieved at the wholesale level. 


\subsection{Impact of increased RES-E production volume on the final price for electricity}

At the retail level, final electricity consumers remained RES-E supporters since the cost of RES-E support schemes were paid by them through the so-called RES-E component included in the final price for electricity. Figure 2 displays the estimated structure of this RES-E component.

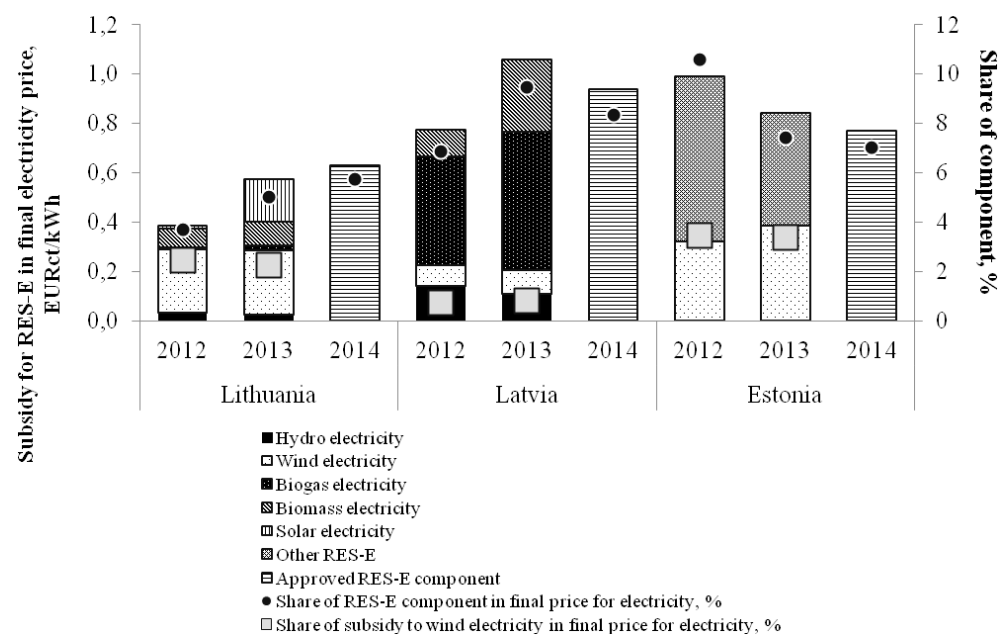

Fig. 2. The RES-E component included in the final price for electricity, EUR ct/kWh (without VAT), in 2013 (own computations).

As seen from Fig. 2, the actual RES-E component ${ }^{1}$ included in the final price for electricity in 2013 was $0.58 \mathrm{EUR} \mathrm{ct} / \mathrm{kWh}$ in Lithuania, $0.84 \mathrm{EUR} \mathrm{ct} / \mathrm{kWh}$ - in Estonia and $1.06 \mathrm{EUR} \mathrm{ct} / \mathrm{kWh}$ - in Latvia. It made 5.0\% in the final price for electricity in Lithuania, 7.4\% - in Estonia and 9.4\% - in Latvia. The actual wind electricity component was $0.8 \%$ of the final price for electricity in Latvia, $2.3 \%$ - in Lithuania and $3.4 \%$ - in Estonia.

In Lithuania, the actual RES-E component increased by $49 \%$ in 2013 . This was mainly caused by high feed-in tariff for solar electricity resulted in increased production volume of solar electricity. In that year, the wind electricity component made up $45.3 \%$ in the structure of RES-E component. Due to increased production volume of wind electricity the actual subsidy increased by $0.01 \mathrm{EUR}$ ct/kWh. In 2014, the National Control Commission for Energy and Prices approved the share of RES-E component in the final electricity price at a rate of $0.63 \mathrm{EUR} \mathrm{ct} / \mathrm{kWh}$ with planned increase in the future.

In Latvia, RES-E component in the final price for electricity increased by $36 \%$ in 2013 - mainly due to the increased volumes of biogas and biomass electricity. The actual component of biomass and biogas electricity was $0.56 \mathrm{EUR}$ ct/kWh and 0.29 EUR ct/kWh, respectively. However, in 2014 the RES-E sector regulating

\footnotetext{
${ }^{1}$ Actual component is a subsidy which is computed based on actual RES-E generation and final electricity consumption volumes. This is an ex-post subsidy. Approved component is a subsidy which is computed by the RES-E sector regulating authority. It is based on the forecasted RES-E production and final electricity consumption volumes. This is an ex-ante subsidy.
} 
authority approved a reduced component. Today, the final electricity consumers pay for the RES-E sector development at a rate of $0.94 \mathrm{EUR} \mathrm{ct} / \mathrm{kWh}$.

In Estonia, the subsidy for RES-E sector development has been decreasing since 2012, although the subsidy for development of wind sector is increasing. The wind electricity component in the final price for electricity increased from 0.32 EUR ct/kWh to 0.39 EUR ct/kWh during 2012-2013.

Thus, the estimations show that the subsidies to wind electricity generators made a relevant share in the final price for electricity and tended to increase in the Baltic States.This means that the wind electricity support schemes were costly in the Baltic States.

\subsection{Net benefits / cost from the promotion of wind electricity sector}

Trends in the assumptions made for estimation of net benefits / cost of the support schemes for wind electricity production and the results achieved are shown in Table 2. Two cases were analysed:

1. Case (1) assumed that the wind electricity component included in the final price for electricity changed due to changes in the subsidy for wind electricity, the wind electricity production volume, and the final electricity consumption volume.

2. Case (2) assumed that the wind electricity component included in the final price for electricity changed due to changes in the subsidy for wind electricity and wind electricity production volume, while the final electricity consumption volume in 2013 was the same as in 2012. Case (2) demonstrates the efficiency of wind electricity support schemes.

Table 2 shows that the trends in the energy sectors were similar in Latvia and Estonia, i.e. increase in the wind electricity production and decrease in the final electricity consumption. This double effect resulted in increased subsidy for the wind electricity share in the final price for electricity. Although the production volumes of wind electricity increased and electricity market prices decreased in the countries, the net impacts of the support schemes for wind electricity production were different.

Calculations show that in 2013 the net cost from wind electricity promotion was received in Estonia, which has the wind electricity support scheme compatible with the electricity market. Direct trade of the wind electricity in the market led to a decrease in the market price, i.e. the greatest decrease was expected in Estonia - by 0.027 EUR ct/kWh (see Fig. 1). However, the reduced final electricity consumption increased the subsidy for wind electricity included in the final price for electricity. As a result, in Estonia the net cost was achieved.

Estimations show that only a minor net benefit was derived in Latvia from the wind energy promotion in 2013 . The reason was the reduced electricity market price due to production of the wind electricity. It is expected that creation of the conditions for improved competition in the power market and integration of the wind electricity into the market (i.e. creation of a direct link between the wind electricity trade and the market as in Estonia) could raise the benefits. Besides, increase in the final electricity consumption could automatically reduce the subsidy for wind generators in the final price for electricity. 
Trends in the assumptions for estimation of net benefits / cost of the support schemes for wind electricity production in the Baltic States during 2012-2013 (own work)

\begin{tabular}{|c|c|c|c|c|c|c|c|}
\hline Country & $\begin{array}{l}\text { Type of sup- } \\
\text { port scheme }\end{array}$ & $\begin{array}{l}\text { Changes } \\
\text { in the } \\
\text { market } \\
\text { price for } \\
\text { electricity }\end{array}$ & $\begin{array}{l}\text { Changes } \\
\text { in the wind } \\
\text { electricity } \\
\text { production }\end{array}$ & $\begin{array}{l}\text { Changes } \\
\text { in the final } \\
\text { electricity } \\
\text { consump- } \\
\text { tion }\end{array}$ & $\begin{array}{l}\text { Changes } \\
\text { in subsidy } \\
\text { for wind } \\
\text { electric- } \\
\text { ity in final } \\
\text { price for } \\
\text { electricity }\end{array}$ & $\begin{array}{l}\text { Changes } \\
\text { in the final } \\
\text { consumer } \\
\text { price for } \\
\text { electricity }\end{array}$ & $\begin{array}{l}\text { Other advantages } \\
\text { and disadvantages } \\
\text { of wind electricity } \\
\text { support scheme }\end{array}$ \\
\hline (1) & (2) & (3) & (4) & (5) & (6) & (7) & (8) \\
\hline Estonia & $\begin{array}{l}\text { Feed-in } \\
\text { premium } \\
\text { when maxi- } \\
\text { mum } 600 \\
\text { GWh of wind } \\
\text { electricity } \\
\text { generated a } \\
\text { year is sup- } \\
\text { ported }\end{array}$ & $\downarrow$ & $\uparrow$ & $=$ & $\uparrow$ & $\begin{array}{c}\uparrow, \text { since } \\
(6)>|(3)|\end{array}$ & $\begin{array}{l}\text { 1. Low predictabil- } \\
\text { ity of profit due to } \\
\text { risks associated with } \\
\text { electricity market } \\
\text { prices. } \\
\text { 2. Reduced windfall } \\
\text { profits. } \\
\text { 3. Improved } \\
\text { compatibility with } \\
\text { electricity market } \\
\text { than in the case of } \\
\text { feed-in tariff. } \\
\text { 4. Lower invest- } \\
\text { ment security than } \\
\text { in the case of feed- } \\
\text { in tariff. }\end{array}$ \\
\hline Lithuania & $\begin{array}{l}\text { Fixed tariff, } \\
\text { when maxi- } \\
\text { mum } 500 \\
\text { MW of in- } \\
\text { stalled wind } \\
\text { capacity is } \\
\text { supported } \\
\text { and wind } \\
\text { electricity is } \\
\text { traded via the } \\
\text { market }\end{array}$ & $\downarrow$ & $\uparrow$ & $\uparrow$ & $\uparrow$ & $\begin{array}{c}\downarrow, \text { since } \\
(6)<|(3)|\end{array}$ & $\begin{array}{l}\text { 1. Limited predict- } \\
\text { ability of profit, } \\
\text { since wind electric- } \\
\text { ity producer takes } \\
\text { the market price } \\
\text { risk. } \\
\text { 2. Increased wind- } \\
\text { fall profits. } \\
\text { 3. Compatibil- } \\
\text { ity with electricity } \\
\text { market. } \\
\text { 3. High investment } \\
\text { security. }\end{array}$ \\
\hline Latvia & $\begin{array}{l}\quad \text { Feed-in } \\
\text { tariff, when } \\
\text { maximum } \\
5.37 \% \text { of } \\
\text { wind electric- } \\
\text { ity from final } \\
\text { consumption } \\
\text { is supported }\end{array}$ & $\downarrow$ & $\uparrow$ & $\downarrow$ & $\uparrow$ & $\begin{array}{c}\downarrow, \text { since } \\
(6)<|(3)|\end{array}$ & $\begin{array}{l}\text { 1. Profit is predict- } \\
\text { able (no market } \\
\text { price risk) when } \\
\text { promotional quata } \\
\text { is high. } \\
\text { 2. Increased wind- } \\
\text { fall profits. } \\
\text { 3. Scheme is not } \\
\text { compatible with } \\
\text { electricity market. } \\
\text { 3. High investment } \\
\text { security. }\end{array}$ \\
\hline
\end{tabular}

At the same time, the moderate benefit in 2013 in Latvia could also be explained by small wind electricity production volume. Of importance is the low public acceptance. Moreover, it was negative in Latvia regarding the installation of wind turbines. For example, a public discussion on new wind farm construction at Koninciems (a populated place in Latvia) was held in mid-2013. Thus, Vejputis Ltd. planned to install eight Enercon E-126 wind turbines, 7.58 MW each (the total capacity of 
$60 \mathrm{MW}$ ), the tower and rotor-wing common height $198.5 \mathrm{~m}$, radius of protection zone $298 \mathrm{~m}$, noise from the nearest estates $<50 \mathrm{~dB}$ [13]. During the discussion, the residents were against the installation of new wind turbines. The people were concerned about artificial shading, high levels of noise, infrasound and magnetic field formation, environmental pollution, negative impact on bird migration and the surrounding countryside. Eventually, the Council rejected the idea of new wind farm construction at Koninciems [14].

In Lithuania, despite the increase in the final electricity consumption, the increased wind electricity production resulted in a higher wind electricity compo-nent in the final price for electricity. However, net benefits were received, since the wind electricity having rather a low variable cost could be traded via the market, thus contributing to market price reduction. The link established between the wind electricity trade and the market allowed achieving net benefits from the promotion.

Figure 3 provides estimations of net benefit / cost from the promotion of wind electricity sector.

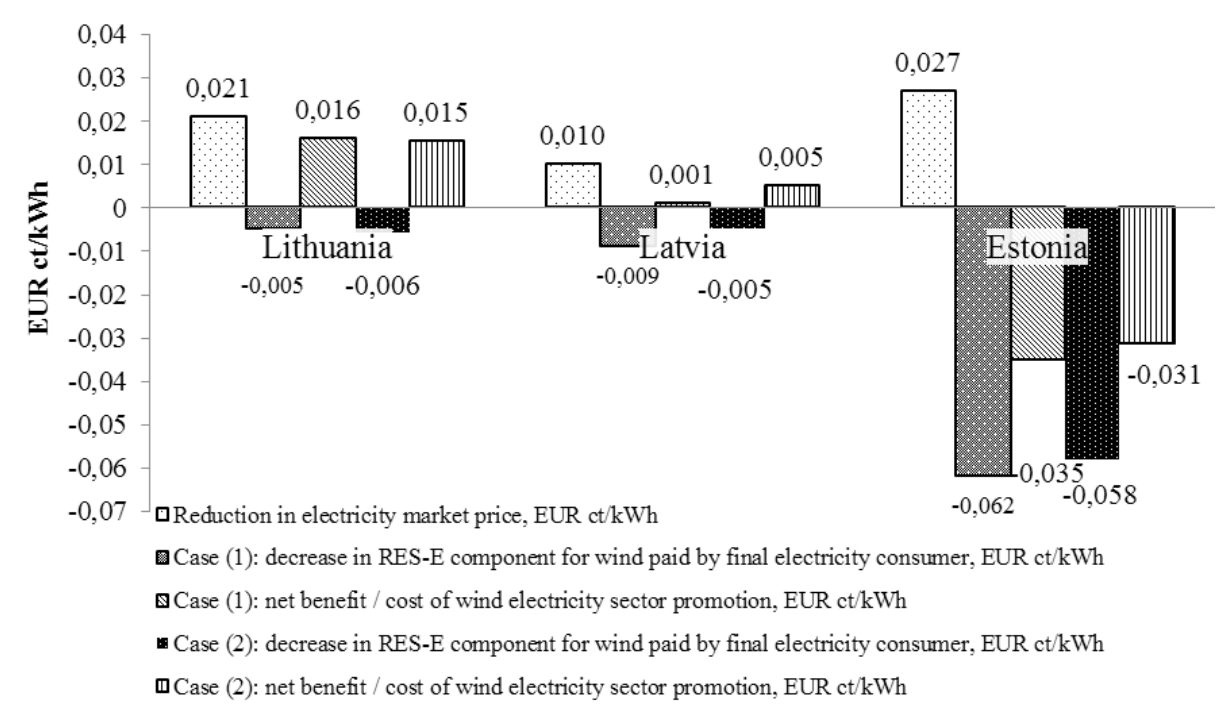

Fig. 3. Net benefit / cost of wind electricity sector promotion, EUR ct/kWh (own computations).

The results obtained at analysis of changes in electricity market prices show that the efficiency of feed-in premium is higher than that of the feed-in tariff support scheme. Direct trade of electricity in the market that is subject to the feed-in premium (Estonia) reduces the electricity market prices more than these are changing at feed-in tariffs (limited RES-E access to the market) applied in Lithuania and Latvia. However, rapid development of the wind electricity sector and reduced final electricity consumption volume resulted in the net cost in Estonia $(0.035 \mathrm{EUR} \mathrm{ct} / \mathrm{kWh}$ or 18.5 million EUR in 2013). Net benefits from the promotion of wind electricity were achieved only in Latvia and Lithuania. Latvia demonstrated minor increases $(0.001$ EUR ct/kWh or 0.11 million EUR) in net benefits in 2013. These benefits could be even higher (0.005 EUR ct/kWh) if the final electricity consumption was not reduced in the country. The case of Lithuania shows that the decrease in electricity market price could be greater than the increase in the wind electricity subsidy (component) 
included in the final price for electricity. Thus, in 2013 a net benefit of 0.016 EUR ct/ $\mathrm{kWh}$ (9.6 million EUR) was derived in the country.

\section{CONCLUSIONS}

1. The economic efficiency of feed-in tariff support schemes that have been implemented in Lithuania and Latvia was higher than that of the feed-in premium employed in Estonia.

2. Integration of wind electricity into the market allows achieving real reductions in the electricity market prices; and as a result, the price benefits increase for the final electricity consumers. The positive effect of wind electricity integration could be strengthened by implementing the strategic electricity network projects and by physically integrating the Baltic States' power systems into the EU ones. This could create preconditions for the international trade in electricity and its import (including RES-E) from neighbouring countries at competitive prices.

3. Improvement of the economic conditions and size of the national economy followed by increasing final electricity consumption volumes led to the reduction in the cost related to wind electricity sector promotion (in terms of EUR ct/kWh).

4. Consistent and long-term RES-E support policy and the related measures should be provided based on the economically substantiated criteria. This will contribute to the achievement of net benefits such as slower growth in the electricity prices for the final electricity consumers.

\section{ACKNOWLEDGEMENT}

The work is supported by the European Social Fund project "Assessment of wind energy potential in Latvia and environmental impact from wind energy installations", No. 2014/0010/1DP/1.1.1.2.0/13/APIA/VIAA/033.

\section{REFERENCES}

1. de Miera, G. S., del Rio Gonzalez, P., \& Vizcaino, I. (2008). Analysing the impact of renewable electricity support schemes on power prices: The case of wind electricity in Spain. Energy Policy, 36, 3345-3359.

2. Gelabert, L., Labandeira, X., \& Linares, P. (2011). An ex-post analysis of the effect of renewables and cogeneration on Spanish electricity prices. Energy Economics, 33, S59S65.

3. Moreno, B., López, A. J., \& García-Álvarez, M. T. (2012). The electricity prices in the European Union. The role of renewable energies and regulatory electric market reforms. Energy, 48, 307-313.

4. Mulder, M., \& Scholtens, B. (2013). The impact of renewable energy on electricity prices in the Netherlands. Renewable Energy, 57, 94-100.

5. Grigas, A. (2013). Energy policy: the Achilles heel of the Baltic States. [Online]. Available: http://www.notre-europe.eu/media/balticstateseu-energypolicy-grigas-ne-jdi-july 13.pdf?pdf $=$ ok. 
6. Lithuanian Energy Market (2011). [Online]. Available: // http://ec.europa.eu/energy/ gas_electricity/doc/lt_energy_market_2011_en.pdf.

7. LITGRID (2014). System Data. [Online]. Available: // http://www.litgrid.eu/index.php/ sistemos-duomenys/79.

8. Elering (2014). Data Archive. [Online]. Available: // http://elering.ee/data-archive/.

9. Augstsprieguma tikls (2014). Current Situation in Power System. [Online]. Available: $/ / \mathrm{http}: / / \mathrm{www}$. ast.lv/eng/power_system/current_situation_ in_power_system/state_of_ power_system/.

10. Nord Pool Spot AS (2014). Historical Market Data. [Online]. Available: // www. http:// www.nordpoolspot.com/Market-data1/Downloads/Historical-Data-Download1/DataDownload-Page/.

11. Benoit, K. (2011). Linear Regression Models with Logarithmic Transformations. Methodology Institute, London School of Economics. [Online]. Available: // http://www.kenbenoit.net/courses/ME104/logmodels2.pdf.

12. Bobinaite, V. \& Konstantinaviciute, I. (2014). Does Electricity From Renewable Energy Sources Reduce Electricity Market Price In Lithuania? The $9^{\text {th }}$ Conference on Electrical and Control Technologies ECT-2014, Kaunas (Lithuania), May 8-9, Technologija, 2014. ISSN 1822-5934, 104-109.

13. Vēja parkam Turlavā - jā vai nē (2013). [Online]. Available: // http://www.kurzemnieks. lv/node/2187.

14. Dambergs, E. (2013). Noraida ieceri būvēt vēja g̊eneratorus Turlavā. [Online]. Available: // http://news.lv/Kuldigas_Novada_Vestis/2013/07/30/Noraida-ieceri-buvet-vejageneratorus-Turlava.

\title{
AER-E ATBALSTA POLITIKA BALTIJAS VALSTĪS: ELEKTROENERĢIJAS CENU ASPEKTS (II DAĻA).
}

\author{
V. Bobinaite, I. Priedite
}

Kopsavilkums

Rakstā analizēta elektroenerǵijas ražošanas no atjaunojamiem energoresursiem (AER-E) palielināšanas ietekme uz elektroenerǵijas tirgus cenu un gala cenu elektroenerǵijas lietotājiem Baltijas valstīs. Daudzfaktoru regresijas analīzes rezultāti atklāja, ka AER-E 2013. gadā varētu samazināt elektroenerğijas tirgus cenas Baltijas valstīs. Tomēr jāṇem vērā, ka elektroenerǵijas lietotāja gala cenā ir iekḷauta AER-E atbalsta komponente, kurai ir raksturīgi palielināties. Aprēķināts, ka no vēja elektroenerǵijas ražošanas Latvijā un Lietuvā tika iegūta tīrā peḷna, bet Igaunijā tikai nosedza pašizmaksu. Tas liecina, ka vēja elektroenerǵijas atbalsta shēmai, kas balstīta uz obligātā iepirkuma atbalsta principu, ir augstāka ekonomiskā efektivitāte, nekā atbalsta shēmai, kas balstīta uz piemaksu par no AER saražoto elektroenerǵiju obligātā iepirkuma ietvaros.

07.01.2015. 